\title{
Land, Water, and Development in Marioriwawo District
}

\author{
Nurfatimah Nurfatimah ${ }^{1}$, Jumliasi Jumliasi ${ }^{2}$, Ardilla Abu $^{3}$, Fadhil Surur ${ }^{4}$, Nursalam Nursalam ${ }^{5}$ \\ ${ }^{1}$ Universitas Islam Negeri Alauddin Makassar, Indonesia \\ Email: nurfatimah.nurfatimah91@gmail.com \\ ${ }^{2}$ STAI DDI Makassar, Indonesia \\ Email: jumliadimh@gmail.com \\ ${ }^{3}$ Institut Agama Islam Negeri Palu, Indonesia \\ Email: ardilla_abu@iainpalu.ac.id \\ ${ }^{4}$ Universitas Islam Negeri Alauddin Makassar, Indonesia \\ Email: fadhil.surur@uin-alauddin.ac.id \\ ${ }^{5}$ STAI DDI Makassar, Indonesia \\ Email: salamnur094@gmail.com
}

\begin{abstract}
This research was conducted to determine carrying capacity of the environment in Marioriwawo District, Soppeng Regency, Sulawesi Selatan Province. The carrying capacities of land for buildings and water were used for analysis in this study, referring to the Regulation of the Minister of Environment No. 17 of 2009. The results showed that the environmental carrying capacity was 78.15 , which was more than 3 , thus categorized safe/good based on the calculation results that $70 \%$ of the carrying capacity of land for buildings was 108.30 hectares and $40 \%$ of the carrying capacity of water was $5.86 \mathrm{~m}^{3} /$ year.
\end{abstract}

Keywords: Carrying capacity; Land; Water; Environment

\section{Introduction}

Carrying capacity of the environment (CCE) is the ability of the environment to support human life, other living things, and the balance between the two [1]. The carrying capacity of the environment of a region is strongly influenced by the increase in the population with all its activities which causes the need for land and water to increase [2]. Regulation of the Minister of Environment Number 17 of 2009 concerning Guidelines for Determination of Carrying Capacity of the Environment in Regional Spatial Planning states that the determination of carrying capacity of the environment is carried out by knowing the capacity of the natural environment and resources to support human/population activities that use space for survival. So, carrying capacity of the environment must obtain special attention to maintain a balance between the needs and the limitations of the environment [3].

Marioriwawo is District in Soppeng Regency, Sulawesi Selatan, Indonesia. Most of the area of this district is a mountainous region and is famous for its cool temperatures, with natural views that are very soothing. Most of the residents' livelihoods in this region are farming, both garden farmers and rice farmers. The most widely produced agricultural products are cocoa and rice. In addition, many residents of this district are traders and employees. This area has the potential to be used as a tourist destination [4]: there are many places that are truly unspoiled, plus views of rice fields that are not less beautiful than Ubud Bali [5].

However, its diverse natural resources make an increase in population which will have an impact on increasing the rate of use of natural resources [6-7], such as reduced availability of natural resources from the forestry sector [8-9] and agriculture, including the use of space for human life and other living things [10-11].

The results of the determination of carrying capacity of the environment can be used as a reference in the preparation of a sustainable spatial plan (RTRW) [12-13] in the Marioriwawo District of Soppeng Regency. The relationship between carrying capacity of the environment and the RTRW 
can be determined by the KLHS (Strategic Environmental Assessment as a tool that can provide a review or evaluation of the RTRW prepared.

The determination of carrying capacity of the environment is carried out using a spatial databased approach, in which spatial information about the characteristics of an area [14], a spatial picture of the designation, and detailed land cover and optimization of environmental-based development efforts can be obtained through Geographic Information Systems (GIS) [15-16]. This study aimed to determine the carrying capacity of the environment of Mariorowawo District, Soppeng Regency.

\section{Research Method}

This research was located in Mariorowawo District, Soppeng Regency, with an area of 59,515 Ha.

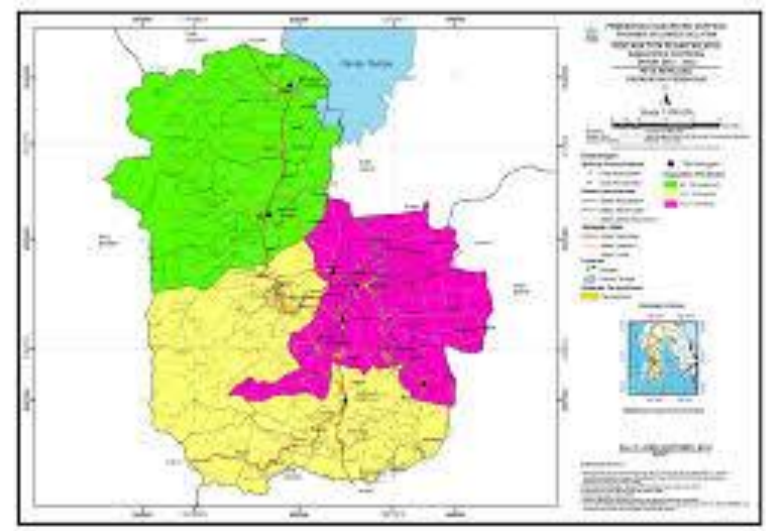

Analysis of the data used in this study was the analysis of the carrying capacities of building/ residential land and water [17-18].

\section{Analysis of Carrying Capacity of Land for Buildings (Residential Area)}

Calculation of land carrying capacity with an approach to building (DDLB) uses an equation that refers to the Regulation of the Minister of Environment No. 17 of 2009 as follows:

$$
\begin{aligned}
& \mathrm{DDLB}=\frac{(\alpha \times \mathrm{LW})}{\mathrm{LTb}} \\
& \mathrm{LTb}=\mathrm{LB}+\mathrm{LTp}
\end{aligned}
$$

Keterangan:

DDLB = carrying capacity of land for buildings

$\mathrm{LW} \quad=$ area (ha)

$\mathrm{LTb}=$ built up area (ha)

LB = building area (ha)

LTp = land area for infrastructure (such as roads, rivers, drainage and others (ha); if it cannot be identified, assume $20 \%$ of the building area).

$\alpha=$ coefficient of the maximum land area developed (ha) (70\% if agriculture $<50 \%$, $50 \%$ if agriculture $>50 \%)$ ).

The calculation results were analyzed with the following categories:

DDLB $<1$ : The carrying capacity of residential land is exceeded or poor

DDLB 1 - 3: The carrying capacity of residential land is conditional or moderate

DDLB > 3: The carrying capacity of residential land is safe or good 


\section{Analysis of Water Resources Carrying Capacity}

Based on the Regulation of the Minister of Environment No. 17/2009, the calculation of carrying capacity of water is carried out by comparing the availability of water (SA) and the demand for water (DA) with the following formula:

$\mathrm{DDA}=\mathrm{SA} / \mathrm{DA}$

where
SA : water availability $\left(\mathrm{m}^{3} /\right.$ year $)$
DA : the demand for water $\left(\mathrm{m}^{3} / \mathrm{tahun}\right)$

\section{Analysis of Water Availability}

The equation for calculating water availability is as follows:

$$
\begin{aligned}
& \mathrm{SA}=10 \times \mathrm{C} \times \mathrm{R} \times \mathrm{A} \\
& \mathrm{C}=\sum(\mathrm{Ci} \times \mathrm{Ai}) / \sum \mathrm{Ai} \\
& \mathrm{R}=\sum \mathrm{Ri} / \mathrm{m}
\end{aligned}
$$

Note:

SA : water availability $\left(\mathrm{m}^{3} /\right.$ year $)$

$\mathrm{C}$ : weighted runoff coefficient

$\mathrm{Ci}$ : land use runoff coefficient

$\mathrm{R}$ : average annual algebraic rainfall in the region $(\mathrm{mm} / \mathrm{year})$

$\mathrm{Ri}$ : annual rainfall

$\mathrm{m}$ : number of rainfall observation stations

A : area (ha)

Ai : land use area (ha)

\section{Analysis of the demand for water}

Calculation of the demand for water was calculated using the following equation:

$$
\mathrm{DA}=\mathrm{N} \times \mathrm{KHL}
$$

Note:

DA : the demand for water $\left(\mathrm{m}^{3} / \mathrm{year}\right)$

$\mathrm{N} \quad$ : total population (soul)

KHL : the demand for water to live properly (1600 $\left.\mathrm{m}^{3} / \mathrm{capita} / \mathrm{year}\right)$

The calculation results were analyzed with the following categories:

DDA $<1$ : Water resources carrying capacity is exceeded or poor

DDA 1 - 3 : Water resources carrying capacity is conditional or moderate

DDA $>3$ : Water resources carrying capacity is safe or good

\section{Analysis of Carrying Capacity of the Environment}

The carrying capacity of the environmental is determined by weighting DDLB 70\% and DDA 40\%

[19]. The following is the DDL calculation:

$\mathrm{DDL}=(70 \% \times \mathrm{DDLB})+(40 \% \times \mathrm{DDA})$

DDL $<1$ : The carrying capacity of the environment is exceeded or poor

DDL $1-3$ : The carrying capacity of the environment is conditional or moderate

DDL $>3$ : The carrying capacity of the environment is safe or good 


\section{Results and Discussion}

\subsection{Carrying Capacity of Land for Building}

Calculation of the carrying capacity of land for buildings (residential land) was done by calculating the area of land for buildings in the study area. To find out the area of land for buildings in Marioriwawo District, image interpretation was performed (Table 1)

Table 1. Data of Land Use in Marioriwawo District

\begin{tabular}{clr}
\hline No. & \multicolumn{1}{c}{ Land Use } & \multicolumn{1}{c}{ Area (ha) } \\
\hline 1 & Forest & 34178.43 \\
2 & Diversified Gardens & 86952.43 \\
3 & Farm/field & 13556.25 \\
4 & Open field & 5605.25 \\
5 & Housing & 632.03 \\
6 & Rice field & 3086.09 \\
7 & Shrubs & 1830.97 \\
8 & Water body/river & 4744.86 \\
Total area & & $\mathbf{1 5 0 5 8 6 . 3 0}$ \\
\hline Region $(\mathbf{L W})$ & & \\
\hline
\end{tabular}

Based on the interpretation of the land for buildings (housing), the area of the land for buildings (housing ) in Mariorowawo District is $632.03 \mathrm{Ha}$ from the total area of $150586.30 \mathrm{Ha}$. From the calculation of land use, it can be concluded that:

Total population (JP)

Kepadatan Penduduk

Area (LW)

Building area (LB)

Land for infrastructure (LTp)

Coefficient of developed land area $(\alpha)$

Coefficient of required land area/capita $(\alpha)$

$$
\begin{aligned}
& \mathrm{LTb}=\mathrm{LB}+\mathrm{LTp} \\
& \mathrm{LTb}=695.24 \mathrm{ha} \\
& \mathrm{DDLB}=\frac{(\alpha \times \mathrm{LW})}{\mathrm{LTb}} \\
& \mathrm{DDLB}=108.30 \text { ha }
\end{aligned}
$$

$$
\begin{aligned}
& =45100 \text { souls } \\
& =0.299 \mathrm{soul} / \mathrm{ha} \\
& =150586.30 \mathrm{ha} \\
& =632.03 \mathrm{ha} \\
& =63.203 \mathrm{ha} \\
& =50 \% \mathrm{ha} / \mathrm{capita} \\
& =0.0133 \mathrm{ha} / \text { capita }
\end{aligned}
$$

Based on the above calculation, the carrying capacity of land for buildings in Marioriwawo District was 108.30 ha, namely DDLB $>3$. The carrying capacity of land for buildings was categorized as safe/good category, so that Marioriwawo District is still able to provide land for buildings/settlements to accommodate a number of residents to live properly.

\subsection{Water Resources Carrying Capacity}


Water resources carrying capacity is the ability of water resources to meet a need by reviewing the water availability [20-21]. Water resources carrying capacity is calculated based on the calculation of water availability and the demand for water.

\subsection{Analysis of Water Availability}

Calculation of water availability is based on the Regulation of the Minister of Environment No. 17 of 2009 concerning Guidelines for Determination of Carrying Capacity of the Environment in Regional Spatial Planning [22]. Based on this, the data needed in the calculation are land availability, weighted runoff coefficient, average algebraic annual rainfall, and area.

\subsubsection{Calculation of Weighted Runoff Coefficient}

Calculation of the weighted runoff coefficient is presented in the following table:

Table 2. Data of Weighted Runoff Coefficient

\begin{tabular}{|l|l|r|r|r|}
\hline No. & \multicolumn{1}{|c|}{ Land Use } & \multicolumn{1}{c|}{$\begin{array}{c}\text { Area/Ai } \\
\text { (ha) }\end{array}$} & \multicolumn{1}{c|}{$\begin{array}{c}\text { Runoff } \\
\text { Coefficient/Ci }\end{array}$} & Ci x Ai \\
\hline 1 & Forest & 34178.43 & 0.18 & 6152.12 \\
\hline 2 & Diversified Gardens & 86952.43 & 0.10 & 8695.24 \\
\hline 3 & Farm/field & 13556.25 & 0.35 & 4744.69 \\
\hline 4 & Open farm & 5605.25 & 0.35 & 1961.84 \\
\hline 5 & Housing & 632.03 & 0.65 & 410.82 \\
\hline 6 & Rice field & 3086.09 & 0.30 & 925.83 \\
\hline 7 & Shrubs & 1830.97 & 0.35 & 640.84 \\
\hline 8 & Water body/river & 4744.86 & 0.00 & 0.00 \\
\hline Total & & $\mathbf{1 5 0 5 8 6 . 3 0}$ & & $\mathbf{2 3 5 3 1 . 3 7}$ \\
\hline
\end{tabular}

Source: Deliniation of Soppeng Regency Image Map

$$
\begin{aligned}
& \mathrm{C}=\frac{\sum(\mathrm{Ci} \mathrm{x} \mathrm{Ai})}{\sum \mathrm{Ai}} \\
& \mathrm{C}=0.16
\end{aligned}
$$

\subsubsection{Calculation of Average Rainfall}

Calculation of average annual rainfall is obtained based on the comparison of annual rainfall to the number of rainfall observation stations [23], as calculated based on the following equation:

$$
\begin{aligned}
& \mathrm{R}=\frac{\sum \mathrm{Ri}}{\mathrm{m}} \\
& \mathrm{R}=1756 \mathrm{~mm} / \text { year }
\end{aligned}
$$

The value of water availability in the Marioriwawo District was obtained based on the following equation:

$\mathrm{SA}=10 \times \mathrm{C} \times \mathrm{R} \times \mathrm{A}$

$\mathrm{SA}=10 \times 0.16 \times 1756 \times 150586.30$ 


$$
\mathrm{SA}=423087268.48 \mathrm{~m}^{3} / \text { year }
$$

\subsection{Analysis of the demand for Water}

Based on the Regulation of the Minister of Environment No. 17 of 2009 concerning Guidelines for Determination of Carrying Capacity of the Environment in Regional Spatial Planning, the calculation of the demand for water can be obtained by multiplying the number of population $(\mathrm{N})$ with the demand for water to live properly (KHL) [24-25]. The number of population based on data from the Central Statistics Agency of Soppeng Regency Marioriwawo District was 45100 people while the demand for water to live properly was $1600 \mathrm{~m}^{3} /$ person/year. Thus, the calculation of water demand:

$$
\begin{aligned}
& \text { DA }=\text { N x KHL } \\
& \text { DA }=45100 \times 1600 \\
& \text { DA }=72160000 \mathrm{~m}^{3} / \text { year }
\end{aligned}
$$

So, the demand for water in Marioriwawo District was $72160000 \mathrm{~m}^{3} / y e a r$. The calculation results were analyzed with the following equation:

$$
\begin{aligned}
\mathrm{DDA} & =\frac{\mathrm{SA}}{\mathrm{DA}} \\
\mathrm{DDA} & =\frac{423087268.48}{72160000} \\
\mathrm{DDA} & =5.86 \mathrm{~m}^{3} / \mathrm{year}
\end{aligned}
$$

Based on the calculation between the availability of water and the demand of water, the carrying capacity of water resources Marioriwawo District was $5.86 \mathrm{~m}^{3} /$ year, namely DDA> 3. The carrying capacity of water was categorized as safe/good because of the large availability of water to meet the needs of the population in Marioriwawo District.

\subsection{The Carrying Capacity of the Environment}

The condition of carrying capacity of the environment in Marioriwawo District can be determined by adding up $70 \%$ of the carrying capacity of the land for buildings and $40 \%$ of the carrying capacity of water resources. So, the results of calculations between the carrying capacity the land for buildings, water resources carrying capacity and environmental carrying capacity of 78.15 was DDLP> 3 . The environmental carrying capacity was categorized as safe/good because there were several supporting indicators, namely the carrying capacity of land for buildings that was safe/good [26] so that there were land for buildings available to accommodate the population to live properly and the carrying capacity of water resources in Marioriwawo District also had greater water availability, compared to the residents' demand for water.

\section{Conclusions}

Based on the aims and results of the study, it can be concluded that the carrying capacity of land for buildings (housing) in Marioriwawo District was 108.30 ha, namely DDLB> 3, which was categorized as safe/good, so that Marioriwawo District was still able to provide land for buildings/housing to accommodate a certain number of residents to live properly. Meanwhile, the water resources carrying capacity of Marioriwawo District was $5.86 \mathrm{~m}^{3} /$ year, namely DDA $>3$, which was categorized as safe/good. This was due to the water availability for the population in Marioriwawo District. Therefore, based on the results, the environmental carrying capacity of the district was 78.15 , namely 
DDLP> 3. So, it can be concluded that the environmental carrying capacity in Marioriwawo District, Soppeng Regency, was categorized as safe/good.

\section{Referensi}

[1] J. La Fua, R. U. Nurlila, F. Gunawan, \& I. S. Wekke 2018 Islamic education on formation of environmental awareness in Indonesian Islamic Boarding Schools In IOP Conference Series: Earth and Environmental Science. IOP Publishing. 1561012035

[2] L. Alfita, A. L. Kadiyono, P. T. Nguyen, W. Firdaus, \& I. S. Wekke 2019 Educating the External Conditions in the Educational and Cultural Environment International Journal of Higher Education, 88

[3] S. Kuraedah, F. Gunawan, I. S. Wekke, \& B. Hamuddin 2018 Learning environment construction in Islamic Higher Education: Connecting the puzzles of ideas In IOP Conference Series: Earth and Environmental Science. IOP Publishing. 1751012107

[4] J. La Fua, I. S. Wekke, Z. Sabara, \& R. U. Nurlila 2018 Development of environmental care attitude of students through religion education approach in Indonesia In IOP Conference Series: Earth and Environmental Science. IOP Publishing. 1751012229

[5] N. N. S. Astuti, G. Ginaya, \& N. P. W. A. Susyarini 2019 Designing Bali tourism model through the implementation of tri hita karana and sad kertih values International journal of linguistics, literature and culture, 51 12-23

[6] A. Khan, F. Muhammad, Y. Chenggang, J. Hussain, S. Bano, \& M. A. Khan 2020 The impression of technological innovations and natural resources in energy-growth-environment nexus: A new look into BRICS economies Science of The Total Environment, 138265

[7] J. Guan, D. Kirikkaleli, A. Bibi, \& W. Zhang 2020 Natural resources rents nexus with financial development in the presence of globalization: is the "resource curse" exist or myth? Resources Policy, 66101641

[8] A. Kumar, S. Adamopoulos, D. Jones, \& S. O. Amiandamhen 2020 Forest biomass availability and utilization potential in Sweden: A review Waste and Biomass Valorization, 1-16

[9] C. Petucco, A. Lobianco, \& S. Caurla 2020 Economic evaluation of an invasive forest pathogen at a large scale: the case of ash dieback in France Environmental Modeling \& Assessment, 25(1), 1-21

[10] I. S. Wekke, B. Samra, N. Abbas, \& N. Harun 2018 Environmental Conservation of Muslim Minorities in Raja Ampat: Sasi, Mosque and Customs In IOP Conference Series: Earth and Environmental Science. IOP Publishing. 1561012038

[11] M. Yusuf, \& I. S. Wekke 2020 Developing Environmental Awareness and Actualizing Complete Piety Based on Quran International Journal of Advanced Science and Technology, 29 05 2039-2050

[12] A. M. Hersperger, M. Bürgi, W. Wende, S. Bacău, \& S. R. Grădinaru 2020 Does landscape play a role in strategic spatial planning of European urban regions? Landscape and Urban Planning, 194103702

[13] M. Świąder, D. Lin, S. Szewrański, J. K. Kazak, K. Iha, J. van Hoof,... \& S. Altiok 2020 The application of ecological footprint and biocapacity for environmental carrying capacity assessment: A new approach for European cities Environmental Science \& Policy, 105 56-74 
[14] Y. Wang, Y. Wang, X. Su, L. Qi, \& M. Liu 2019 Evaluation of the comprehensive carrying capacity of interprovincial water resources in China and the spatial effect Journal of Hydrology, 575 794-809

[15] L. P. Utomo, I. A. Saputra, \& Z. Nisa 2020 Mapping education facilities based on geographic information system In IOP Conference Series: Earth and Environmental Science. IOP Publishing. 4851012104

[16] T. Tampubolon, R. Juliani, J. Hutahean, \& J. Yanti 2020 Deformation Mapping of the 2018 Sulawesi Earthquake by Satellite Radar and Optical Remote Sensing. In Journal of Physics: Conference Series. IOP Publishing. 14281012043

[17] E. R. P. Simanjuntak, J. Sumabrata, H. A. Simarmata, \& A. Zubair 2020 Analysis of Water Carrying Capacity in Cibinong Urban Development. In IOP Conference Series: Earth and Environmental Science. IOP Publishing. 4361012003

[18] X. Wei, L. Shen, Z. Liu, L. Luo, J. Wang, \& Y. Chen 2020 Comparative analysis on the evolution of ecological carrying capacity between provinces during urbanization process in China. Ecological Indicators, 112106179

[19] B. Liu, J. Chang, L. Xiao, G. Qin, B. Wei, \& Z. Huo 2019 DDLB: A Dynamic and Distributed Load Balancing Strategy In 2019 IEEE 21st International Conference on High Performance Computing and Communications; IEEE 17th International Conference on Smart City; IEEE 5th International Conference on Data Science and Systems (HPCC/SmartCity/DSS). IEEE. 19281936

[20] X. Y. Zhou, B. Zheng, \& S. T. Khu 2019 Validation of the hypothesis on carrying capacity limits using the water environment carrying capacity Science of the Total Environment, 665 774-784

[21] D. Hermon, E. Erianjoni, I. Dewata, A. Putra, \& O. Oktorie 2019 Liquefaction Vulnerability Analysis as a Coastal Spatial Planning Concept in Pariaman City-Indonesia International Journal of Recent Technology and Engineering (IJRTE), 82 4181-4186

[22] H. E. Beck, N. Vergopolan, M. Pan, V. Levizzani, A. I. Van Dijk, G. P. Weedon,... \& E. F. Wood 2020 Global-scale evaluation of 22 precipitation datasets using gauge observations and hydrological modeling In Satellite Precipitation Measurement. Springer, Cham. 625-653

[23] F. Bedecarrats, O. Lafuente-Sampietro, M. Leménager, \& D. L. Sowa 2019 Building commons to cope with chaotic urbanization? Performance and sustainability of decentralized water services in the outskirts of Kinshasa Journal of Hydrology, 573 1096-1108

[24] A. Di Giulio, \& R. Defila 2019 The ,good life 'and Protected Needs “. Kalfagianni, Agni; Fuchs, Doris, und Anders Hayden (Hrsg.). The Routledge Handbook of Global Sustainability Governance. London, Routledge.

[25] Z. Liu, Y. Ren, L. Shen, X. Liao, X. Wei, \& J. Wang 2020 Analysis on the effectiveness of indicators for evaluating urban carrying capacity: A popularity-suitability perspective Journal of Cleaner Production, 246119019

[26] S. Fotios 2019 Using category rating to evaluate the lit environment: Is a meaningful opinion captured? Leukos, 15 2-3 127-142 